DOI: 10.17234/SRAZ.65.31

UDK: $323.15(439=135.1)$

UDK: $81^{\prime} 246.2(439=135.1)$

Original scientific paper

Primit la 30 aprilie 2020

Acceptat pentru publicare la 25 noiembrie 2020

\title{
Cercetare sociolingvistică longitudinală asupra identităţii româneşti din Ungaria ${ }^{1}$
}

\author{
Ana Borbély \\ Centrul de Cercectări Lingvistice ELKH, Budapesta \\ borbely.anna@nytud.hu
}

Studiul îşi propune să evidenţieze chestiunea autoidentificării ca români a unor vorbitori bilingvi, originari din comunitatea istorică a românilor din Ungaria, întrebați, într-o situație de interviu semistructurat, de trei ori, în două decenii. Răspunsurile dezvăluie componentele identităţi de naţionalitate românească şi modificările prin care ele trec în perioada cuprinsă între anul 1990 (după prăbușirea regimului socialist) şi anul 2010 (după aderarea la UE).

Cuvinte-cheie: identitate, naționalitate, limbă, românii din Ungaria, cercetare longitudinală

\section{Limbă şi identitate de naționalitate}

Construcția identității lingvistice are mai multe dimensiuni. Joseph despre corelaţia între limbă şi identitate afirmă că, tot ceea ce spune sau scrie un individ, atât în ceea ce priveşte forma cât şi conținutul, are un rol central în definirea identității acestuia (2004: 225). Construcția identității a unui individ în interiorul unui grup este complexă, întrucât - printre altele - acumulează emoții, simboluri, atitudini, tradiții, practici, procese cognitive, acomodări la diferite ideologii, circumstanțe istorice, sociale, politice şi situaționale. Coulmas despre intensitatea identităților individuale susține că, apartenența la grupuri sociale şi identitare a fiecărui individ variază şi se schimbă sub influența contextului şi timpului (2005: 179). Nu avem încă o cercetare comparativă a identității româneşti din România cu cele ale grupurilor istorice din medii alogene. În cele ce urmează, vom analiza doar datele unei investigaţii longitudinale concrete, realizată în comunitatea istorică a românilor din Ungaria, în localitatea

1 Cercetarea s-a efectuat în Centrul de Cercetări Lingvistice - Academia Ungară de Ştiințe/ Rețeaua de Cercetare Eötvös Loránd (ELKH) Budapesta, cu sprijinul proiectelor OTKA T 030305, OTKA K 81574, RIL-HAS Languag-E-Chance Educational Research Group project SZ-007/2016 (2016-2021) coord. Csilla Bartha şi Academia Ungară de Ştiințe PROJEKT 2017-55 (NKM 115/2018-37/2019-8/2020). 
Chitighaz (ung. Kétegyháza), ${ }^{2}$ pentru a descoperi modificările apărute, într-un interval de 20 de ani, în chestiunea identificării persoanelor ca români în ceea ce privește limba şi identitatea. Legea actuală (2011/CLXXIX) din Ungaria pentru cele 13 comunităţi etnice - cu limbă, cultură etc. proprie, care se află de cel puțin un secol în țară - foloseşte conceptul de „naţionalitate”. Pe baza acestui concept din lege, vom analiza, deci, identitatea de naționalitate a românilor din Ungaria, care, în consecință, cuprinde principiile de identitate românească şi de cetățenie ungară.

\section{Schimbări istorice şi sociale}

Comunitatea istorică a românilor din Ungaria de azi, transformată numeric (şi nu numai), în mod considerabil după Primul Război Mondial, la începutul secolului XX trăia o viaţă tradițională: vorbind limba română, respectând regulile religiei ortodoxe ori baptiste, tradiţiile şi normele comunităţilor româneşti. Aceste puncte comune i-au unit într-un grup şi i-au separat de unguri şi de celelalte naţionalităţi din țară. În Chitighaz, la sfârşitul secolului XX, în 1990, data primei anchete sociolingvistice, cei în vârstă şi cei de vârstă medie trăiau încă o viața tradițională românească, vorbeau româneşte, dar cu ungurii aveau contacte tot mai frecvente (serviciu, reviste, radio, televizor). Cei tineri, născuți deja într-o viață modernă, într-un mediu cu unele relicve păstrate din viața tradițională, vorbesc tot mai puțin româneşte. În amalgamul schimbărilor petrecute în societate şi în comunitate, în secolul nostru, coeziunea de grup (tradițional românesc) se dizolvă pe zi ce trece.

\section{Metode de cercetare}

Cercetarea sociolingvistică longitudinală în comunitatea românilor din Chitighaz are ca scop, în principiu, analiza bilingvismului român-maghiar (v. Borbély 2016). Proiectul cuprinde trei anchete de teren, începând cu anul 1990 şi repetate în anul 2000 şi în anul 2010. Până în momentul de față, au fost culese date de la 361 de persoane/participanți în cercetare (în continuare: participanți), dintre care de la 33 la toate anchetele. Participanții au fost selectați după vârstă, gen şi educaţie; toți fiind consideraţi, de anchetator/autor, ca reprezentanţi ai românilor, având părinţi români sau fiind foşti elevi la şcoala românească,

2 Localitate la 20 km de granița ungaro-română, unde, după recensământul din 2011 (v. KSH), dintre 3808 de persoane, 1050 s-au declarat români. Biserica Ortodoxă Română funcţionează aici, exclusiv în limba română, măcar din anul 1718; învățământul confesional în limba română din anul 1793. În Biserica Baptistă, înfiinţată în anul 1892, serviciile divine sunt bilingve, dar, începând cu anii 1990, cu o proporţie tot mai redusă este folosită limba română şi, concomitent, cu o proporţie tot mai mare este folosită limba maghiară. Azi şcoala bilingvă are denumirea: Şcoala Generală şi Grădiniţa Română din Chitighaz. Alături de asociațiile culturale româneşti, din 1994, românii sunt susţinuți şi de o autoguvernare românească locală. 
mireni ortodocşi sau baptişti etc. Răspunsurile analizate mai jos, au fost culese în graiul român local (v. Borbély 1990), prin înregistrări audio, care au inclus: un chestionar, un interviu semistructurat pe module şi un test de lexic. Unul dintre module era consacrat identităţii româneşti, fiind amplasat în ultima parte a interviului şi introdus cu întrebărea: Dumńeta/Tu t'e țîi râmân?, urmând întrebarea (deschisă): De ce?, formulat, cu gândul de a obține acele repere identitare cu care, un chitighăzean român, vorbind româneşte în fața microfonului, cu un român originar din Chitighaz, îşi defineşte identitatea de naţionalitate (românească). Problematica are o deosebită semnificație dacă luăm în considerare afimația lui Edwards (1985: 163): „identitatea de grup va supraviețui schimbării de limbă”, mutatis mutandis, românii din Ungaria se vor identifica ca români şi după ce nu vor mai vorbi româneşte.

Datele statistice arată că în 1990, din eşantionul de 60 de persoane 44 s-au autoidentificat ca români. $\mathrm{O}$ analiză calitativă a datelor longitudinale vor fi analizate conform ipotezelor de cercetare formulate pe baza unor probleme teoretice.

1) Gleason (1996: 468, citat de Stachel 2007: 13) analizând identitatea etnică afirmă că, în discursurile politice, se deosebeşte opinia primordialiştilor de cea a opționaliştilor. ${ }^{3}$ După primordialişti identitatea etnică este moştenită, este un dat, şi ca urmare este un fenomen stabil. Opționaliştii au opinie opusă, identitatea etnică fiind considerată o construcție dependentă de context, şi care poate fi transformată. Dacă identitatea de naționalitate românească este moştenită, identitatea participanților - ale căror răspunsuri urmează să fie analizate - după 10, 20 de ani nu se va schimba (prima ipoteză).

2) Contextul sociolingvistic, schimbarea limbii române în limba maghiară, cu alte cuvinte, abandonarea limbii române în favoarea limbii maghiare, poate fi un factor care va determina schimbarea identității de naționalitate românească (v. Borbély 2005). Dat fiind că, comunitatea cercetată se află în procesul de schimbare a limbii române în limba maghiară, şi alegerea limbii române în comunicare arată corelatie cu identitatea de naționalitate română, după 10, 20 de ani participanții se vor declara unguri şi nu români (a doua ipoteză).

3) Teoria de negociere a identităţii (v. de ex. Pavlenko/Blacklegde ed. 2004) pune accentul pe actualele schimbări sociale, economice şi politice, care influențează opțiunile dintr-un anumit moment istoric ce vor sta la dispoziția construcțiilor identitare. Dar construcțiile identitare sunt supuse şi acelor ideologii, care legalizează şi valorifică, mai mult sau mai puțin, într-un moment dat, o identitate față de alta. În consecinţă, identitatea este totdeauna o negociere de context şi de moment istoric, sau „,constant renegociată" - cum scrie Schifirneț (2009: 462, cu referire la Brubaker/Cooper 2000: 2). In cercetarea de față, contextul cuprinde: (a) nivelul istoric, social, economic, politic, ideologic şi (b) nivelul situației de interviu dirijat şi înregistrat. Toate aceste nivele se modifică, prin cele trei anchete, în timp. Identitatea nu se poate modela după 10, 20 de ani (a treia ipoteză).

3 În alte lucrări, cu privire la identitate, apar categoriile: esenţialism şi constructivism (v. de ex. Brubaker/Cooper 2000; Hale 2004; Schifirneț 2009). 
În cele ce urmează vom analiza răspunsurile, extrase din 15 interviuri, colectate de la 5 participanți (P20, P25, P43, P81, P82), ${ }^{4}$ bărbați, născuți între anul 1954 şi anul 1971, cu o pregătire de cel puțin 12 clase.

\section{Analiza calitativă a răspunsurilor longitudinale}

Rezumând conținutul răspunsurilor, putem afirma că, identitatea de naţionalitate se explică în relație cu anumite concepte: cetăţenie (ungară, alegeri), limbă (română, maghiară), societate (avantaj), familie (generaţii) şi emoţii (metafore: inimă, naştere, casă). Un specific fundamental este că, unii participanți nu fac (ştiu să facă) diferența între identitate de naţionalitate (românească) şi cetățenie (ungară), cu toate că, într-un grup minoritar, ele au conţinuturi deosebite. Dacă căutăm coincidențe între răspunsurile participanților se desprind o seamă de asemănări, pe baza cărora participanții pot fi împărțiți în trei tipuri.

Tipul A (P25): se declară consecutiv ungur, şi după 10 şi după 20 de ani, cu menţiunea că, pe parcursul acestor două decenii argumentele lui se schimbă. În 1990, după ce se declară ungur, aminteşte locul, țara unde trăieşte (Ungaria), adică cetățenia se îmbină cu identitatea de naţionalitate. Argumentul al doilea este limba română, care i se pare important de adăugat. După 10 ani, cetăţenia ungară rămâne ca primul argument, iar limba română nu mai este amintită, şi, paralel, ca un mod nou de exprimare, răspunsul este dat în limba maghiară. Iar după 20 de ani, participantul nu este de acord cu înregistrarea interviului şi, răspunsul lui, rostit în ungureşte, devine afectiv: am inimă ungurească. Prin urmare, evoluarea identității de naţionalitate este cu totul evidențiată: ungur cu limbă română; cetățean ungur; inimă ungurească. Autoidentificarea participantului, în cei 20 de ani, se realizează, mai cu seamă, conform ipotezei a doua, influențată de contextul sociolingvistic: abandonarea limbii române în favoarea limbii maghiare.

Tipul B (P20 şi P43): în 1990 se declară ungur şi în cei 20 de ani care urmează evoluează, se autoidentifică drept român. P20 după 10 ani dă un răspuns nehotărât (nu totdeauna român), deci evoluarea identităţii sale trece prin trei etape. În 1990 ungur, în 2000 nu totdeauna român şi în 2010 român. P43 la prima anchetă, când se declară ungur, deja exprimă o ezitare: dar simt că sunt român. Peste 10 ani ezitarea rămâne, dar deja după ce se autoidentifică român, prin amintirea sarcinilor de cetățean maghiar: dar la votare ungur trebuie să fiu. După 20 de ani, însă, identitatea românească este declarată fără nicio ezitare. Evoluarea identităţii de naţionalitate românească la aceşti doi participanţi se realizează prin cele mai însemnate schimbări. Ajung în 20 de ani să se declare români, cu toate că la prima anchetă s-au declarat unguri. În acest tip de evoluare identitară apar cele mai multe ezitări, explicații, confuzii. Evoluarea identității de naționalitate la ei se realizează mai cu seamă conform ipotezei a treia, în concordanţă cu teoria negocierii identităţii, adaptare la contextul istoric, social, economic, politic şi ideologic din perioada

4 Participanții (P) cercetării erau identificați, în anul 1990, cu aceste numere, semnalând ordinea interviurilor realizate la anchetă. 
prăbușirii regimului socialist până după aderarea la UE. De asemenea, nu poate fi neglijat nici contextul situaţiei de înregistrare (microfon).

Tipul C (P81 şi P82): în 1990 se declară român, ceea ce nu se schimbă nici după 10 şi nici după 20 de ani. Însă în argumentare se arată şi aici o evoluare, un progres. La prima anchetă ambele persoane au ținut să vorbească despre rolul unui român în societatea ungară: să fii român, nu este un avantaj (P81), ori nu este nici un bine, nici un rău (P82). La a doua anchetă argumentele se diversifică. Apare ca argument nou limba şi generația copiilor, primul (P81) precizând că şi-au învățat copiii să vorbească şi să citească româneşte, deoarece ei n-au frecventat şcoală românească. Celălalt (P82) îşi explică identitatea românească împreună cu accentuarea locului, țării (Ungaria) unde trăieşte. Peste 20 de ani identitatea românească, la amândoi, se explică pe scurt şi cu argumente afective. P81 revine la identitatea primită prin naştere, la fel şi P82, cu explicaţia unei metafore: să fii român, este să fii acasă. Primul drum al evoluării începe de la o identitate românească fără niciun avantaj şi ajunge la o identitate primită prin familie, deci total stabilă (v. P81). La fel, şi al doilea parcurs porneşte de la o identitate care nu este nici ceva bun, nici ceva rău şi ajunge la faza în care este primită prin familie, ca apoi să ajungă la o identitate care înseamnă să fii acasă, adică în stabilitate (v. P82). În „,final” evoluarea identității de naţionalitate românească la aceşti doi participanţi, după 20 de ani, este conform primei ipoteze (identitatea românească este obţinută prin naştere), dar, până ce traiectoria evoluării ajunge la acest punct, trece prin faze care ating ipoteza a doua (v. argumentul limbii române), şi ipoteza a treia (contextul timpului real şi al timpului din viața participanţilor).

\section{Concluzii}

Evoluarea identității de naționalitate pentru fiecare individ este un proces unic, cu unele asemănări şi coincidențe. Rezultatele analizei arată că, identitatea de naţionalitate românească nu este stabilă pentru toți (v. prima ipoteză), ea se schimbă în timp, pe baza contextelor sociolingvistice: istorice, sociale, economice, ideologice şi situaţionale (v. a doua şi a treia ipoteză). În acelaşi timp, în viaţa fiecărui individ se desfăşoară şi o continuă schimbare cognitivă şi psihologică, acestea având (şi) consecințe identitare. Stabilitatea familială, economia prosperă, apartenența la o comunitate bisericească (v. Borbély 2004) pot fi factori care determină sau/şi ajută exprimarea identităţi româneşti şi în contextul sociolingvistic de schimbare a limbii române în limba maghiară şi privind contextul de situație de interviu. Problematica construcției identităţii şi prin analiza acestor date calitative-longitudinale s-a demonstrat complexă, pornind, printre altele, de la faptul că analiza nu se poate reduce la o singură ipoteză, bazată pe o singură concepție teoretică, - cum afirmă de ex. şi Hale (2004). În concluzie se poate sublinia că, autoidentificarea ( $\hat{n} n$ cazul de faţă, într-o perioadă de 20 de ani) în viața unui individ (i) se schimbă, se transformă, evoluează; (ii) identitatea moştenită (v. prima ipoteză) pentru tineri nu are aşa de mare importanță (v. prima anchetă, 1990), dar se arată importantă cu trecerea timpului în viaţa aceloraşi indivizi (v. a treia anchetă 2010). 


\section{Bibliografie}

Borbély, Ana (1990). Cercetări asupra graiurilor românești din Ungaria, Budapest: Tankönyvkiadó.

Borbély, Ana (2004). Relația dintre biserică şi menţinerea limbii minoritare, in: Simpozion, Comunicările celui de-al XIII-lea Simpozion al cercetătorilor români din Ungaria (Giula, 29-30 noiembrie 2003) [red. Maria Berényi], Giula: Publicație a Institutului de Cercetări al Românilor din Ungaria, pp. 182-193.

http://www.romanintezet.hu/index.php/hu/kiadvanyok/2004/11-simpozion/45simpozion-2004

Borbély, Anna (2005). Changes in bilingual language choice influenced by real and apparent time, in: ISB4: Proceedings of the 4th International Symposium on Bilingualism [eds. James Cohen / Kara T. McAlister / Kellie Rolstad / Jeff MacSwan], Somerville, MA: Cascadilla Press, pp. 328-340.

Borbély, Anna (2016). Sustainable bilingualism and language shift: longitudinal research in Romanian-Hungarian bilingual Kétegyháza (Hungary), in: Acta Linguistica Hungarica 63(1), pp. 23-61.

Brubaker, Rogers / Frederick Cooper (2000). Beyond "identity", in: Theory and Society, 29, pp. 1-47.

Coulmas, Florian (2005). Sociolinguistics: The study of speakers' choices, Cambridge: Cambridge University Press.

Edwards, John (1985). Language, society and identity, Oxford, UK: Blackwel Publishing.

Gleason, Philip (1996). Identifying identity: A semantic history, in: Theories of ethnicity. A classical reader [ed. Werner Solors], New York: New York University Press, pp. 460-487, [prima ediţie 1983].

Hale, Henry E. (2004). Explaining ethnicity, in: Comparative Political Studies, 37(4), pp. 458-485.

Joseph, John E. (2004). Language and identity: national, ethnic, religious, New York: Palgrave Macmillan.

Pavlenko, Aneta / Blackledge, Adrian (ed.) (2004). Negotiation of identities in multilingual contexts, Clevedon, UK: Multilingual Matters.

Schifirneț, Constantin (2009). Identitatea românească în contextul modernității tendențiale, in: Revista Română de Sociologie, 20(5-6), pp. 461-480.

Stachel, Peter (2007). Identitás - A kortárs társadalom- és kultúratudományok egy központi fogalmának genezise, inflálódása és problémái, in: Regio, 18(4), pp. 3-33.

KSH = Népszámlálás 2011. (2011). Budapest: Központi Statisztikai Hivatal, $<$ https://www.ksh.hu/nepszamlalas/reszletes_tablak> (27/04/2020). 


\section{Sociolinguistic and longitudinal research on Romanian ethnic identity in Hungary}

This paper examines bilingual subjects' twenty years changes in defining their own affiliation to their Romanian ethnic group, which can be characterized with a RomanianHungarian language shift process. In this circumstance the statement "group identity can survive language shift" (Edwards 1985: 163) has a special importance. The same Romanian subjects (members in the historic group) living in Hungary were asked (with direct and indirect questions) three times (in 1990, 2000, and 2010) in semi-structured interviews (tape-recorded). Based on subjects' responses mainly three types of ethnic identity changes could be detected during the twenty years. One of them was in synchrony with the longitudinal trend of Romanian-Hungarian language shift process. Subjects included in the second type confirmed strongly their Romanian ethnic group identity in 2010 despite the fact that they rejected it in 1990 (and in 2000). Subjects from the third type declared themselves consecutively having Romanian identity. These types of twenty years changes were strongly influenced by historic time (including the period from the collapse of socialist regime to the EU membership of Hungary), and the lifespan of the subjects (getting older makes the importance to go back to ethnic group roots).

Key words: identity, nationality, language, Romanians in Hungary, longitudinal research 
